\title{
CONGENITAL SCOLIOSIS: AN ARTICLE REVIEW
}

\author{
Komang Agung Irianto ${ }^{1}$, Hizbillah Yazid ${ }^{2 *}$ \\ ${ }^{1}$ Staff of Orthopaedic and Traumatology Department, Faculty of Medicine, Universitas \\ Airlangga, Dr Soetomo General Hospital, Surabaya \\ ${ }^{2}$ Resident of Orthopaedic and Traumatology Department, Faculty of Medicine, Universitas \\ Airlangga, Dr Soetomo General Hospital, Surabaya
}

*Corresponding Author: Hizbillah Yazid, Resident of Orthopaedic and Traumatology Department, Faculty of Medicine, Universitas Airlangga, Jl. Mayjen Prof. Dr. Moestopo 6-8, Surabaya

E-mail : hizbillahyazid@gmail.com

\begin{abstract}
ABSTRAK
Latar Belakang: Skoliosis kongenital (SK) diartikan sebagai deviasi lateral dari tulang belakang yang terjadi pada saat pertumbuhan intra uterin, dengan insidensi antara 0,5-1 dari 1000 kelahiran. Angka kematian meningkat pada kasus yang tidak mendapat penanganan, khususnya disebabkan masalah pernafasan (40\%).

Isi: SK dapat bervariasi mulai hemivertebra (HV) baik tunggal atau jamak, bar vertebra dengan atau tanpa HV, vertebra batang, vertebra berbentuk baji atau kupu-kupu. Faktor risiko progresifitas termasuk: tipe kelainan, lokasi kelainan, dan usia pasien. Foto polos radiologi masih menjadi diagnosis standar. Evaluasi MRI dapat dipertimbangkan. Tujuan tata laksana SK adalah untuk mencapai keseimbangan batang tubuh dan tulang belakang sambil mempertahankan sebanyak mungkin pertumbuhan normal tulang belakang dan mencegah deficit neurologis. Tata laksana non-operatif meliputi observasi, brace, dan traksi. Prosedur bedah dibagi ke dalam kelompok besar (a) Mencegah deformitas lebih lanjut: fusi in situ, hemiepifisiodesis cembung, dan eksisi HV, (b) Mengoreksi deformitas saat ini: hemiepifisiodesis \& hemiartrodesis, batang tumbuh tunggal dan ganda, eksisi HV, dan osteotomi rekonstruktif.
\end{abstract}

Ringkasan: Tata laksana SK tetap menjadi aspek yang menantang dalam bidang orthopaedi anak. Terapi operatif digunakan jika tidak terpenuhinya kriteria untuk terapi non-operatif atau mengalami kegagalan.

Kata kunci: Skoliosis Kongenital, skoliosis anak, tulang bengkok

\begin{abstract}
Background: Congenital Scoliosis (CS) defined as vertebral lateral deviation which forms during the intrauterine embryonic phase, carrying incidence between 0,5-1 per 1000 births. Mortality rate increases in untreated case, especially due to pulmonary problem (40\%).

Contents: CS can range from hemivertebrae (HV) which may be single or multiple, vertebral bar with or without HV, block vertebrae, wedge shaped or butterfly vertebrae. The risk factors for progression include: type of defect, site of defect, and the patient's age. Plain radiographs remain standard diagnosis. MRI evaluation should be considered. The goal of managing CS is to obtain a balanced trunk and spine while maintaining as much normal spinal growth as possible and preventing neural deficit. Non-operative management is including observation, brace, and traction. The operative procedures are broadly divided into (a) those preventing further deformity: in situ fusion, convex hemiepiphysiodesis, and HV excision, (b) those that correct the present deformity: hemiepiphyseodesis \& hemiarthrodesis, single \& dual growing rods, HV excision, and reconstructive osteotomy.
\end{abstract}


Conclusion: The treatment of CS remains one of the more challenging aspects of pediatric orthopaedic surgery. Operative treatment should be reserved for patients whom non-operative management didn't meet the criteria or failed.

Keywords: Congenital scoliosis, pediatric scoliosis, crooked back

\section{PENDAHULUAN}

Deskripsi pasien dengan kelainan tulang belakang dan metode untuk terapinya telah didokumentasikan oleh tenaga kesehatan sejak awal peradaban manusia. ${ }^{1}$ Kelainan tulang belakang dapat terjadi pada usia berapa pun, mulai dari kelainan kongenital hingga onset baru pada usia lanjut. $^{2}$ Kelainan tulang belakang dapat menyebabkan dampak bagi pasien karena nyeri, penurunan kemampuan untuk melakukan aktivitas sehari-hari, dan depresi. ${ }^{3}$

Insidensi dan prevalensi belum diketahui secara pasti. Penelitian pada populasi besar berdasarkan penemuan tidak sengaja dari X-Ray dada untuk tuberculosis menyimpulkan insidensi untuk tulang belakang regio torakal $0,5-1: 1000$ kelahiran.,5 Angka kematian meningkat pada pasien dengan skoliosis yang tidak mendapat penanganan, terutama karena kegagalan sistem pernafasan $(40 \%)$. Hasil temuan studi postmortem pada pasienpasien tersebut menunjukkan paru yang sangat kecil dengan penurunan jumlah alveoli yang nyata. $2,6,7$

Terapi skoliosis kongenital merupakan salah satu hal yang paling menarik bagi ahli bedah yang menangani kelainan tulang belakang. Fokus penanganannya yaitu pada diagnosis dini dan tindakan operatif sebelum terjadi pembungkukan nyata. $^{2}$

\section{ISI}

\section{Definisi}

Skoliosis kongenital didefinisikan sebagai pembengkokan tulang belakang ke arah lateral akibat gangguan pada proses somatogenesis. Proses tersebut meliputi kegagalan pembentukan maupun segementasi tulang belakang, atau kombinasi dari kedua proses tersebut. Istilah kongenital digunakan karena munculnya kelainan ini didapatkan sejak lahir. Skoliosis kongenital juga dihubungkan dengan adanya satu atau lebih tulang belakang yang terbentuk secara ireguler. ${ }^{8}$

\section{Embriologi}

Tabung saraf terbentuk pada minggu ke-3 masa embrional. Sel paraxial mesoderm menyatu untuk membentuk 42 hingga 44 pasang somite. Somite kemudian berkembang menjadi sklerotom, myotom, dan dermatom. Hubungan antara saraf spinal yang berasal dari tabung saraf dengan pusat sklerotom serta arteri segmental yang tumbuh di antara sclerotom memiliki peranan yang penting. ${ }^{9}$

Pada pergeseran metamerik, sisi kranial pada masing-masing sclerotome bergabung dengan sisi kaudal sklerotom yang tepat berada di atasnya. Arteri segmental melalui perbatasan badan vertebra yang baru terbentuk (terdiri dari hemisklerotom yang berdekatan dari dua sklerotom yang terpisah) dan saraf spinal melalui antar badan vertebra. Hal tersebut seperti diilustrasikan pada gambar 1 .
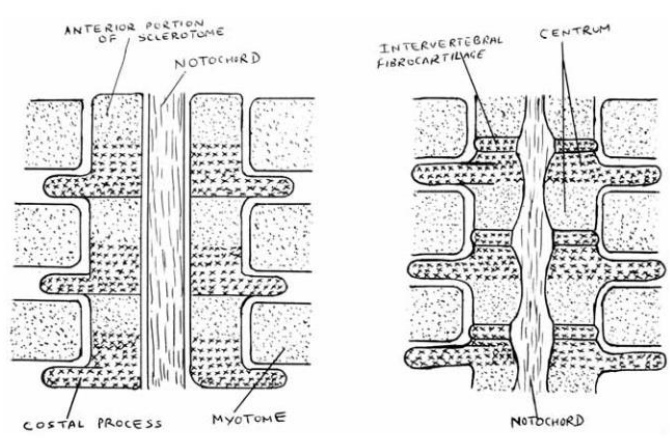

Gambar 1. Ilustrasi proses perkembangan centrum vertebra dari dua segmen pada kedua sisi yang berdekatan ${ }^{10}$ 
Skoliosis kongenital berhubungan dengan kegagalan segmentasi (hemivertebra tidak tersegmentasi dari batang yang tidak tersegmentasi) atau kegagalan pembentukan (hemivertebra). Beberapa teori yang menjelaskan kelainan kongenital tulang belakang meliputi kegagalan proses osifikasi sebagai penyebab kelainan pembentukan, metaplasia tulang pada annulus fibrosus sebagai penyebab kegegalan segmentasi, serta perkembangan tulang belakang yang terhambat oleh notochord yang persisten. ${ }^{10}$

\section{Morfologi}

Tidak terbentuknya satu pedikel dan separuh badan vertebra menyebabkan hemivertebra. Hemivertebra dapat tak tersegmentasi jika berfusi dengan badan vertebra yang berdekatan; tersegmentasi sebagian jika berfusi dengan badan vertebra di atas atau bawahnya; dan tersegmentasi komplit jika dipisahkan dengan diskus dari badan vertebra atas dan bawahnya (gambar 2 dan 3). Hemivertebra dapat terjadi pada badan vertebra yang berdekatan pada satu sisi sehingga berdampak pada pertumbuhan yang asimetris. Hemivertebra dapat diimbangi oleh lainnya pada sisi berlawanan yang dipisahkan dengan satu atau beberapa vertebra sehat, yang disebut hemimetameric shift. Hemivertebra biasa muncul sebagai segmen tambahan tulang belakang dan sering disertai tulang rusuk tambahan. Hal ini dapat terjadi akibat pembelahan yang abnormal pada pusat osifikasi primer.
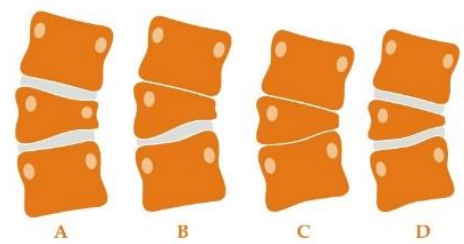

Gambar 2. Representasi kegagalan pembentukan - (A) Vertebra baji (B) Hemivertebra tersegmentasi sempurna (C) Hemivertebra tersegmentasi sebagian (D) Hemivertebra tak tersegmentasi

Bar unilateral dapat menjadi penghambat pertumbuhan dan terkadang dapat membentuk formasi kelainan pada sisi yang sama, sehingga terbentuk bar unilateral dan hemivertebra kontralateral. Tipe campuran sulit dideteksi saat lahir hingga $30 \%$ tulang belakang mengalami penulangan. Kelainan paling banyak terjadi pada apex kurva. Kurva paling banyak yaitu regio torakalis (64\%), diikuti torakolumbalis (20\%), lumbal (11\%), dan lumbosakral $(5 \%) .{ }^{11}$

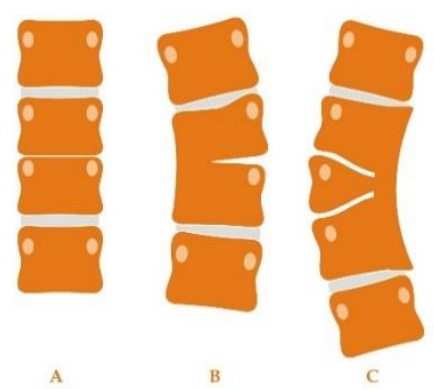

Gambar 3. Representasi kegagalan segmentasi - (A) Vertebra blok (B) Bar tersegmentasi sebagian (C) Kombinasi hemivertebra dan bar tak tersegmentasi

\section{Etiologi}

Penyebab dari kelainan tulang belakang kongenital masih belum diketahui secara pasti. Penelitian pada mencit menunjukkan bahwa paparan pada induk hamil oleh karbondioksida mungkin menyebabkan skoliosis kongenital. Beberapa paparan lain pada kehamilan termasuk penggunaan alkohol, pengobatan antikonvulsi seperti asam valproat, hipertermia, diabetes mellitus tergantung insulin pada ibu hamil, dan diabetes mellitus gestasional diduga berhubungan dengan terjadinya kelainan tulang belakang kongenital pada penelitian hewan dan manusia.

Faktor kimia lain, termal, nutrisi, trauma, dan infeksi juga memiliki dampak. Pada kebanyakan kasus didapatkan interaksi antara faktor genetik dan lingkungan yang harus dinilai sebagai etiologi yang multifaktorial. ${ }^{5,6}$ 


\section{Klasifikasi Skoliosis Kongenital}

Skoliosis kongenital diklasifikasikan pada 3 grup utama:
a. Kegagalan segmentasi
b. Kegagalan pembentukan
c. Bentuk campuran

Sekitar $80 \%$ dari kelainan pada skoliosis kongenital adalah kegagalan segmentasi atau pembentukan, dengan $20 \%$ bentuk campuran.
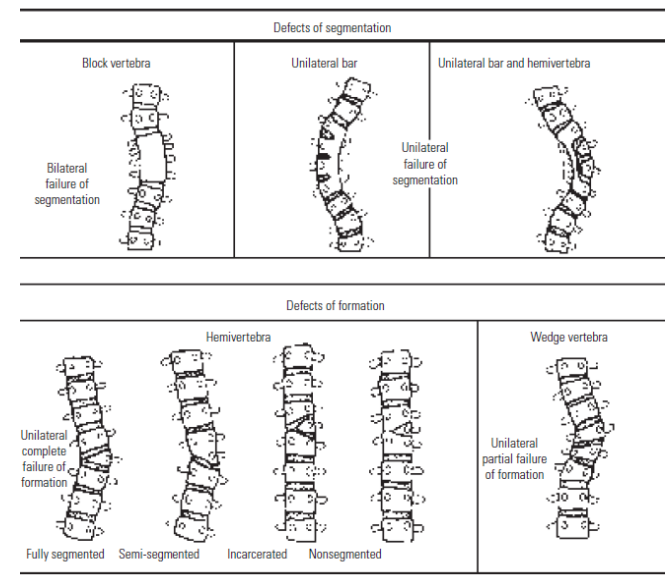

Gambar 4. Klasifikasi skoliosis kongenital menunjukkan kegagalan formasi dan segmentasi. ${ }^{14}$

Hemivertebra diklasifikasikan lebih jauh lagi dengan ada atau tidaknya fusi dari badan tulang belakang baik di atas maupun di bawah:

a. Hemivertebra tak tersegmentasi yang berfusi dengan badan tulang belakang di atas dan di bawahnya

b. Hemivertebra tersegmentasi sebagian yang berfusi dengan badan tulang belakang baik di atas atau di bawahnya

c. Hemivertebra yang tersegmentasi sempurna dan terpisah dari badan tulang belakang di atas dan di bawahnya dengan diskus intervertebralis.

Kelainan pada segmentasi menyebabkan hubungan tulang yang abnormal antar tulang belakang. Hubungan tulang tersebut dapat bilateral dan simetris yang menyebabkan block vertebrae, atau mungkin unilateral. Secara garis besar, klasifikasi tersebut seperti diilustrasikan pada gambar 4.

\section{Proses Alamiah Skoliosis Kongenital}

Studi oleh Winter et al, McMaster, dan Otsuka, yang mengkaji total 485 pasien, menyimpulkan bahwa derajat malformasi dan tingkat keparahan deformitas dapat diprediksi sesuai dengan jenis anomali dan lokasi kurva. Kurva torak bagian atas cenderung lebih tidak parah dibandingkan kurva torakolumbalis, yang cenderung paling parah. Progresivitas kurva terjadi lebih cepat pada 5 tahun pertama kehidupan serta selama periode pertumbuhan pubertas remaja; dua periode ini merupakan tahapan yang paling cepat pertumbuhan tulang. Hal tersebut seperti contoh kasus yang diilustrasikan pada gambar 5 .
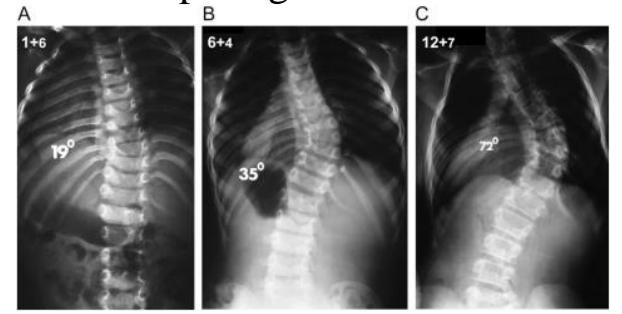

Gambar 5. Radiologi anteroposterior tulang belakang menunjukkan pasien dengan bar tak tersegmentasi unilateral pada sisi kiri sepanjang T8-T10, menghasilkan skoliosis torakal kanan. (A) Pasien anak usia 1,5 tahun dengan kurva torak terhukur $19^{\circ}$, tidak ada terapi yang dilakukan. (B) Saat usia 6 tahun 4 bulan, kurva torak meningkat hingga $35^{\circ}$. (C) Saat usia 12 tahun 7 bulan, kurva torak mencapai $72^{\circ} .^{13}$

Skoliosis kongenital yang diakibatkan kegagalan segmentasi satu sisi vertebra memiliki prognosis yang buruk untuk progresivitas kurvatura dan deformitas. Batang yang tidak tersegmentasi tidak memiliki lempeng pertumbuhan sehingga tidak dapat tumbuh secara longitudinal. Sedangkan pertumbuhan tetap terjadi pada sisi kontralateral menyebabkan skoliosis yang progresif hingga tulang matur.

Dengan dikenalinya jenis malformasi tulang belakang, skoliosis kongenital dapat diklasifikasikan berdasarkan risiko perkembangan kurva 
sehingga tindak lanjut dapat disesuaikan. Deformitas bar tak tersegmentasi unilateral, direkomendasikan untuk mendapat pengobatan pada saat ditemukan karena memiliki kecenderungan progresivitas yang parah. Kurva toraks memiliki prognosis paling buruk, dengan anomali paling buruk adalah bar tak tersegmentasi unilateral dikombinasi dengan satu atau beberapa hemivertebra cembung, diikuti oleh bar tak tersegmentasi unilateral, hemivertebra cembung ganda, hemivertebra cembung tunggal, dengan prognosis paling baik adalah vertebra blok.

Kombinasi deformitas campuran dan anomali tulang rusuk dapat menyebabkan berkurangnya ruang rongga dada serta tinggi dan lebar dada, sehingga berdampak pada pengurangan volume yang besar dan pembatasan gerak, menyebabkan kegagalan pernapasan. $^{10}$

\section{Kelainan Lain yang Terkait dengan Skoliosis Kongenital}

Kelainan kosmetik terjadi pada kebanyakan kurva. Batang tubuh cenderung menjauh dari apex kurva, dan hal ini menyebabkan kesusahan dalam ambulasi dan keseimbangan. Aspek lain yang penting adalah identifikasi adanya kelainan yang muncul bersamaan pada sumsum tulang belakang, ginjal, dan jantung pada $61 \%$ pasien dan bahkan dalam angka yang lebih tinggi pada pasien dengan kelainan campuran. ${ }^{13}$

Kelainan sumbu saraf didapatkan pada sampai dengan $35 \%$ pasien, seperti yang dideteksi dengan MRI. Pasien dengan kelainan campuran atau segmentasi memiliki risiko paling besar. Kelainan ini termasuk (namun tidak terbatas pada) diastematomyelia (split cord), cord tethering, Malformasi Chiari, dan lipoma intradural. Lesi lain dari medula spinalis yang ditemukan pada skoliosis kongenital meliputi kista dermoid, kista epidermoid, teratoma, dan lipoma serta tethered spinal cord dan itu semua mungkin memerlukan pengobatan sebelum operasi tulang belakang untuk meminimalkan risiko cedera saraf berikutnya. Dengan tingginya insiden anomali intraspinal tersebut, disarankan untuk dilakukan skrining MRI rutin pada pasien dengan skoliosis kongenital. ${ }^{21}$

Kelainan tulang belakang kongenital juga diketahui berhubungan dengan Sindrom VACTERL (malformasi tulang belakang, atresia anal, malformasi jantung, trakeo-esofagus fistula, ginjal, dan anomali radial, dan cacat anggota gerak tubuh). ${ }^{6}$ Perkembangan fungsi paru terbatas juga perlu diperhatikan. Pembatasan ini mungkin lebih disebabkan hipoplasia perkembangan paru daripada penyempitan fisik oleh karena kurva; alveoli terus berkembang pada pertumbuhan anak hingga usia 8 tahun. Skrining kapasitas vital dianjurkan untuk pasien dengan kurva yang berat. ${ }^{10,15}$

\section{Pemeriksaan Klinis}

Evaluasi klinis dimulai dengan anamnesis dan pemeriksaan fisik yang komprehensif. Riwayat prenatal ibu, termasuk semua masalah kesehatan, kehamilan sebelumnya, dan obat-obatan dikumpulkan. Riwayat kelahiran anak harus mencakup rincian seperti lama masa kehamilan, jenis persalinan (vagina atau caesar), berat lahir, dan komplikasi. Keterlambatan perkembangan kognitif telah terbukti berkorelasi dengan progresifitas kurva pada beberapa pasien, sehingga perlu diperhitakan apakah anak telah mencapai tahap pertumbuhan dengan baik.

Pemeriksaan fisik dimulai dengan pengukuran tinggi dan berat pasien, mengingat bahwa pertumbuhan memegang peran penting dalam perkembangan kurva. Kulit harus diperiksa untuk menemukan kelainan seperti bintik "café au lait" atau bintik-bintik pada ketiak seperti terlihat pada neurofibromatosis dan patch berambut pada garis tengah sebagai bukti disrafisme tulang belakang. Disrafisme tulang belakang juga dapat bermanifestasi pada ekstremitas bawah, dengan tanda-tanda meliputi betis asimetris, kaki cavus, clubfeet, talus vertikal, dan pemeriksaan neurologis yang abnormal. 
Pemeriksaan tulang belakang berfokus pada ketidak-seimbangan trunkal atau panggul, seperti pada gambar 6. Kelainan tulang rusuk, dada atau panggul yang asimetris, serta gerak dan kelainan dada perlu dievaluasi, demikian juga kapasitas inspirasi dan ekspirasi kapasitas dari dinding dada.

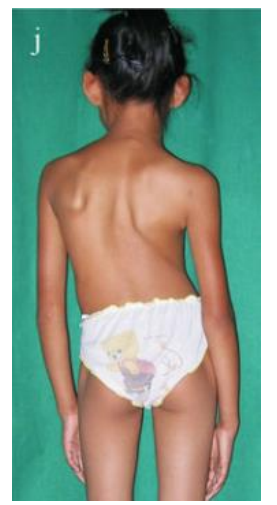

Gambar 6. Dekompensasi batang tubuh dan kemiringan panggul berhubungan dengan skoliosis kongenital ${ }^{16}$

Pada pasien anak yang masih kecil, Adams forward bending test (untuk mencari penonjolan tulang rusuk pada tulang belakang dada atau processus transversus pada tulang belakang lumbal) tidak mungkin dilakukan. Tetapi tes tersebut dapat disimulasikan dengan meletakkan anak dalam posisi tengkurap di atas lutut pemeriksa. Fleksibilitas kurva dapat dinilai dengan menempatkan anak dalam posisi lateral di atas lutut pemeriksa atau dengan menahan bayi di atas lengan pemeriksa.

Keseimbangan tulang belakang pada dimensi koronal dan sagital harus dievaluasi. Ketidakseimbangan trunkal, kemiringan kepala, ketidaksetaraan bahu, dan keseimbangan panggul harus dievaluasi. Pemeriksaan motorik, sensorik, dan refleks (termasuk refleks perut) yang teliti harus dilakukan. Skrining kapasitas vital telah direkomendasikan untuk pasien dengan kurva yang berat. Tata laksana dianjurkan jika operasi direncanakan pada pasien dengan kapasitas vital $<60 \%$ dari normal. ${ }^{10,15}$

\section{Pemeriksaan Radiologis}

Foto polos radiologis tetap menjadi standar untuk skoliosis kongenital dalam mengukur besar kurva, perkembangan kurva, serta potensi pertumbuhan kelainan tulang belakang seperti pada gambar 7 . Radiografi konvensional sering menemui kesulitan dalam penafsiran karena ukuran pasien yang kecil, deformitas yang kompleks, adanya struktur yang menumpangi dan menutupi visualisasi, serta kelainan tulang belakang dalam satu dimensi berbeda dengan yang lain.

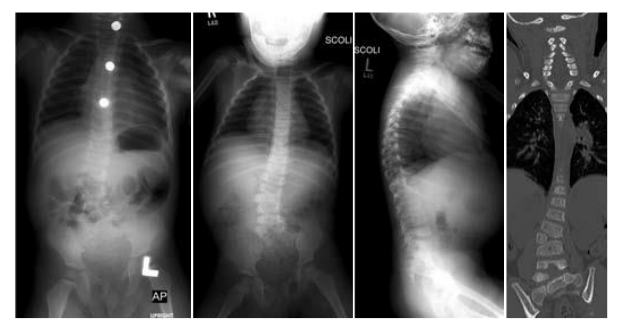

Gambar 7. Skoliosis kongenital lumbosakral progresif pada pasien anak laki-laki usia 2 tahun. (A) Radiografi postero-anterior (PA) posisi berdiri pada usia 18 bulan. (B) Radiografi PA posisi berdiri pada usia 2 tahun tampak progresi skoliosis lumbosakral. (C) Radiografi lateral dengan lordosis lumbar yang sedikit berkurang. (D) CT Scan rekonstruksi koronal menggambarkan hemivertebra lumbal dan hemivertebra lumbosakral. ${ }^{14}$

CT scan preoperasi dapat membantu menentukan anatomi dan menghindari kekurangan elemen posterior yang tak terduga saat operasi. CT juga membantu dalam evaluasi deformitas dinding dada dan volume paru pada kelainan kongenital dengan anomali dinding dada, deformitas dada, atau insufisiensi toraks.

Magnetic Resonance Imaging (MRI) lebih unggul dibandingkan foto polos maupun myelografi untuk mengidentifikasi dan mengevaluasi kondisi perkembangan awal sumbu saraf karena dapat memberikan informasi lebih banyak dan lebih tidak invasif. Dengan menggunakan MRI, Bradford et al melaporkan bahwa 38\% dari 42 pasien pada penelitian mereka didapatkan 
kelainan intraspinal, seperti pada gambar 8. ${ }^{14,19}$

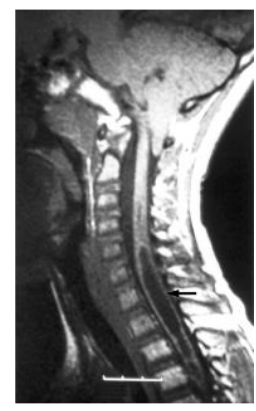

Gambar 8. Skrining MRI sagital T1 pada pasien dengan skoliosis kongenital menunjukkan malformasi Arnold-Chiari ${ }^{17}$

\section{Manajemen Skoliosis Kongenital}

Tata laksana pada skoliosis kongenital tetap menjadi salah satu hal yang penuh tantangan di bidang bedah ortopedi anak. Observasi, casting, ortosis, traksi, dan terapi operatif masih merupakan pilihan untuk pengobatan skoliosis dini. Tindakan operatif harus disiapkan untuk pasien yang tidak memenuhi kriteria untuk observasi, manajemen ortosis, atau jika manajemen ortosis mengalami kegagalan. ${ }^{10}$

\section{Manajemen Non-Operatif Skoliosis Kongenital}

\section{Penggunaan Brace}

Penggunaan brace memiliki peran yang terbatas pada tata laksana pasien dengan skoliosis kongenital, khususnya sebagai bentuk terapi utama karena kurva yang tidak kaku. Batra et al menyebutkan data bahwa kurang dari $10 \%$ kurva kongenital dapat diterapi dengan penggunaan brace. Milwaukee brace direkomendasikan pada pasien dengan kurva tinggi dan TLSO (Thoracic-Lumbar-Sacral Orthosis) pada kurva lumbal. ${ }^{18}$

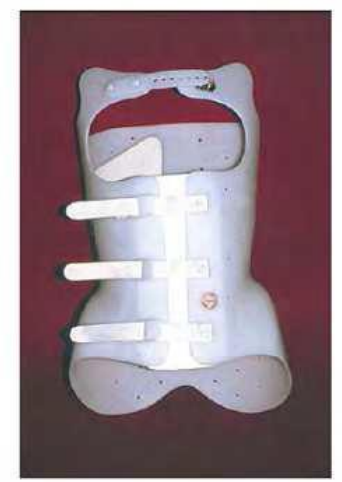

Gambar 9. Cheneau Brace $e^{19}$

Sebagai alternatif, Cheneau et al menyimpulkan dari penelitian pada pasien dengan skoliosis kongenital karena kegagalan pembentukan bahwa penggunaan Cheneau brace (gambar 9) dapat merubah potensi pertumbuhan tulang belakang dengan bentuk baji. ${ }^{19}$

\section{$\underline{\text { Traksi Gravitasi Halo }}$}

Traksi gravitasi halo digunakan sebelum operasi dan efektif untuk memaksimalkan koreksi deformitas yang kaku. Traksi ini ditoleransi dengan baik oleh pasien karena mereka diperbolehkan pergi dari tempat tidur ke kursi roda atau walker dengan traksi. ${ }^{14}$

\section{Manajemen Operatif Skoliosis Kongenital}

Pada dasarnya, telah diakui secara luas dalam berbagai penelitian bahwa terapi bedah lebih mampu untuk mencegah deformitas dan upaya koreksi pada tahap berikutnya. Tujuan dari tindakan operasi adalah untuk mencapai tulang belakang yang lurus, profil sagital yang fisiologis sambil mempertahankan fleksibilitas, untuk menghentikan perkembangan kurva dan fusi segmen sependek mungkin, serta mempertahankan sebanyak mungkin pertumbuhan normal tulang belakang.

Winter dan Lonstein dalam penelitiannya menyatakan bahwa fusi tulang belakang dini memberikan hasil yang jauh lebih baik dibandingkan fusi pada fase lanjut maupun terapi non-operatif. ${ }^{20}$ Kaspiris et al juga menyimpulkan bahwa pasien dengan 
skoliosis kongenital akibat kegagalan segmentasi seharusnya diterapi dengan tindakan operatif sedini mungkin, berkenaan dengan laju progresivitas deformitas. ${ }^{21}$

Secara luas, prosedur pembedahan dibagi menjadi:

(a) Prosedur untuk mencegah deformitas lebih lanjut

(b) Prosedur untuk memperbaiki deformitas saat ini; dibedakan lagi menjadi teknik yang mengoreksi kurva secara bertahap dan koreksi kurva secara akut. ${ }^{10}$

\section{Pencegahan Deformitas yang Akan Terjadi}

\section{Fusi In Situ}

Fusi in situ memungkinkan stabilisasi kurva yang diperkirakan akan memburuk atau telah tercatat terdapat perburukan. Teknik ini adalah tata laksana ideal untuk kurva yang kecil dan jika dilakukan pada waktu yang tepat dapat mencegah kurva membesar.

McMaster serta Winter dan Moe merekomendasikan fusi in situ profilaksis dini untuk mencegah pertumbuhan yang tidak seimbang pada tulang belakang pada sebuah bar tidak tersegmentasi unilateral, dengan atau tanpa hemivertebra sisi kontralateral, dengan hasil terbaik dilaporkan sebelum usia dua tahun. Pendapat bahwa fusi tulang belakang dini akan menghambat pertumbuhan tulang belakang pada pasien usia muda tidak relevan karena bar yang tidak tersegmentasi tidak berkontribusi terhadap pertumbuhan vertikal, namun hanya membuat tulang belakang lebih bengkok.

\section{Convex Hemiepiphysiodesis/}

\section{Hemiarthrodesis}

Teknik ini diindikasikan untuk kondisi kegagalan pembentukan unilateral hemivertebra. Karena masih adanya potensi pertumbuhan yang cukup pada sisi cekung, prosedur ini merupakan kontraindikasi pada kelainan segmentasi, seperti bar yang tidak memiliki potensi pertumbuhan sisi cekung.
Salah satu contoh kasus seperti yang diilustrasikan pada gambar 10 .

Teknik ini mampu menghambat sebagian pertumbuhan pada sisi cembung dengan sisa pertumbuhan, serta sedikit atau tidak ada pertumbuhan pada sisi cekung. Beberapa koreksi dapat dicapai dengan berjalannya waktu, tergantung pada usia dan potensi pertumbuhan pada saat teknik ini dikerjakan. Hasil jangka panjang menunjukkan bahwa dapat dicapai total koreksi $<15^{\circ}$, dengan beberapa pasien tidak mengalami koreksi pada kurva ataupun ketidakseimbangan batang tubuh.

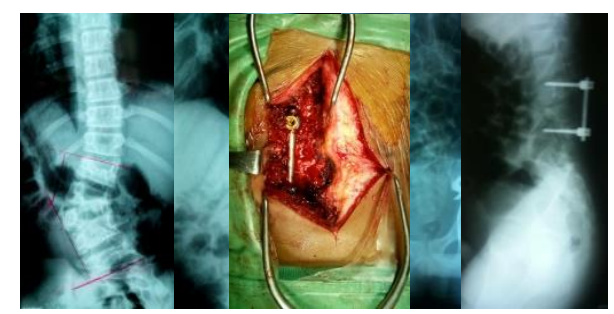

Gambar 10. Radiografi AP (A) dan lateral (B) pre-operasi pasien anak laki-laki usia 15 tahun dengan hemivertebra pada L5-S1. (C) Foto diambil di tengah operasi pemasangan sekrup pedikel pada kurva cembung setelah terlebih dahulu dilakukan eksisi lempeng pertumbuhan. Radiografi AP (D) dan lateral

(E) dilakukan segera setelah pembedahan.

Epiphysiodesis dilakukan dengan menghilangkan setengah diskus pada lateral sisi cembung yang berdekatan dengan hemivertebra, tanpa paparan terhadap tulang belakang pada sisi cekung. Prosedur ini biasanya dilakukan dengan approach anterior (terbuka maupun torakoskopi), ekstirpasi diskus dan tulang rawan pertumbuhan, fusi anterior dan hemiartrodesis posterior tulang belakang pada sisi cembung segmen yang sama (sisi cekung tidak terlibat karena dapat mengarah kepada fusi spontan), dan imobilisasi pasca operasi dengan cast atau brace dengan posisi yang sesuai.

\section{Eksisi Hemivertebra}

Teknik ini sebaiknya dilakukan sekitar usia 2 tahun ketika anak masih bisa mentolerir cast dan fusi lebih 
memungkinkan. Teknik ini mampu menghasilkan koreksi hampir penuh pada fusi segmen yang pendek dan dapat dilakukan melalui approach anteroposterior atau hanya approach posterior. Untuk menutup celah setelah reseksi hemivertebra tersebut, instrumentasi kompresi diperlukan dan memungkinkan untuk fiksasi yang kuat ke vertebra yang berdekatan, seperti pada gambar $11 .^{10,14}$

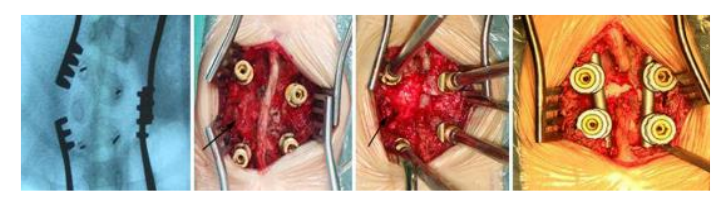

Gambar 11. (A) Fluoroskopi digunakan untuk memastikan level yang benar. (B)

Sekrup pedikel diposisikan setelah tapping. (C) Hemivertebra beserta diskus di atas dan bawahnya dibuang seluruhnya. (D) Celah yang tersisa setelah reseksi ditutup dengan kompresi dan dilakukan fusi posterolateral. ${ }^{24}$

\section{$\underline{\text { Koreksi Deformitas Saat Ini }}$}

Koreksi deformitas yang sudah terjadi saat ini meliputi koreksi secara bertahap maupun segera. Koreksi bertahap diperoleh melalui penggunaan hemiepiphysiodesis dan/atau hemiarthrodesis tulang belakang. Koreksi segera dapat dicapai melalui beberapa teknik yang berbeda: eksisi atau decancellisation hemivertebra dan instrumentasi definitif atau bertahap menggunakan batang tumbuh (growing rod). Untuk pasien dengan sindrom insufisiensi rongga dada, thoracoplasty ekspansi dan stabilisasi melalui VEPTR menjawab masalah ini dengan memisahkan tulang rusuk pada sisi cekung kurva. Untuk kelainan yang kaku, mungkin perlu dilakukan osteotomi untuk menyeimbangkan tulang belakang dan memperbaiki deformitas kosmetik.

\section{a. Koreksi bertahap}

Hemiepiphysiodesis dan Hemiarthrodesis

$\begin{array}{llr}\begin{array}{c}\text { Teknik } \\ \text { kegagalan }\end{array} & \text { ini digunakan } & \begin{array}{r}\text { untuk } \\ \text { pembentukan }\end{array} \\ \text { dengan }\end{array}$

mengandalkan kemampuan pertumbuhan sisi cekung tulang belakang. Pada kegagalan segmentasi, tidak terdapat potensi pertumbuhan yang akan terjadi. Prosedur ini tidak dapat mengoreksi kurva dengan potensi pertumbuhan cekung yang rendah seperti yang disebabkan oleh hemivertebra cembung. Banyak koreksi yang berhubungan dengan hemiepiphysidesis dicapai secara langsung pada saat prosedur awal, sehingga pasca operasi, gips korektif digunakan untuk mendorong fusi tulang belakang dalam posisi koreksi, sehingga meningkatkan titik awal dan memungkinkan koreksi akhir dengan tidak mengandalkan pertumbuhan tulang belakang. Koreksi total yang diperoleh dengan melakukan hemiepiphysiodesis cembung bervariasi karena semakin muda anak pada saat operasi, semakin banyak potensi yang ada untuk koreksi dari waktu ke waktu. ${ }^{10,14}$

\section{$\underline{\text { Batang Tumbuh (Growing Rods) }}$}

Pertumbuhan tulang belakang paling pesat adalah selama 5 tahun pertama kehidupan dengan tinggi duduk mencapai dua pertiga dari tingkat dewasa, sementara volume rongga dada mencapai $30 \%$ dari ukuran dewasa dengan usia lima tahun tersebut. Skoliosis kongenital berhubungan dengan perawakan pendek dan berkurangnya tinggi batang tubuh. Fusi panjang dilakukan pada anak usia dini mungkin memiliki efek mengurangi lebih lanjut ketinggian batang tubuh dan volume rongga dada, yang menyebabkan insufisiensi rongga dada. Dengan tidak adanya fusi tulang rusuk kongenital, kelainan bentuk progresif dini mungkin paling baik diterapi dengan teknik batang tumbuh (growing rod), yang dipelopori oleh Paul Harrington pada 1960-an. Jika anak masih sangat muda, kurva kongenital primer dapat diterapi dengan fusi in situ, hemiepiphysiodesis dan/atau hemiarthrodesis, eksisi, atau osteotomi. Kurva yang telah dikoreksi kemudian dapat ditata laksana dengan growing rod sampai anak lebih dewasa, seperti pada gambar 12. Hal 
ini diperlukan untuk menghindari fusi seluruh kurva, yang akan menyebabkan keterlambatan pertumbuhan dan efek pada paru yang berpotensi membahayakan. ${ }^{10,14}$

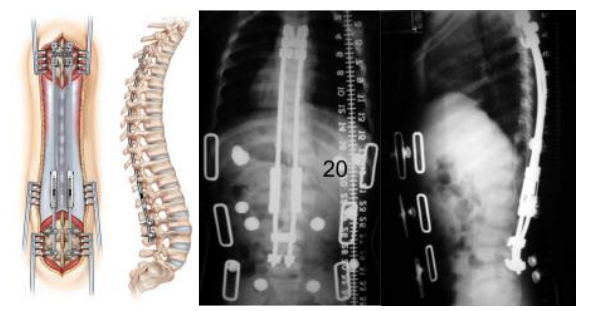

Gambar 12. (A) Gambar menunjukkan teknik batang tumbuh ganda (dual growingrod). Radiografi anteroposterior (AP) (B) dan lateral $(\mathrm{C})$ tulang belakang pascaoperasi dengan teknik ini. ${ }^{26}$

\section{b. Teknik Koreksi Akut}

\section{$\underline{\text { Koreksi dan Fusi dengan Instrumentasi }}$}

Koreksi sebagian atau total dari deformitas tergantung pada kelainan kongenital dan tingkat kelainan itu sendiri. Penentuan level fusi menjadi sulit ketika didapatkan beberapa kelainan yang tidak berdekatan namun tujuannya harus mencapai tulang belakang yang seimbang dengan teknik koreksi seaman mungkin. Seluruh kurva harus menyatu, namun mungkin didapatkan segmen yang abnormal di atas atau di bawah kurva yang tidak akan disertakan dalam instrumentasi. Kurva dada dan leher yang tinggi memerlukan tindakan pencegahan sebagaimana over koreksi dari kurva dada atau torakolumbalis yang lebih rendah dapat menyebabkan ketidakseimbangan bahu atau kemiringan leher. Kelainan kongenital terkait dengan segmentasi yang relatif normal, fleksibilitas (seperti diungkapkan oleh radiografi), dan deformitas batang tubuh yang tidak terlalu parah dapat ditata laksana dengan cara arthrodesis posterior standar dan instrumentasi. Kasus-kasus dengan ruang diskus yang tampak jelas pada pencitraan radiologis menunjukkan bahwa pertumbuhan yang tersisa cukup signifikan; pasien ini mungkin berisiko mengalami fenomena crankshaft dan memerlukan tambahan operasi anterior pembebasan dan fusi anterior, baik dengan operasi terbuka maupun torakoskopi. Jumlah koreksi yang dihasilkan dengan instrumentasi pada skoliosis kongenital biasanya jauh lebih sedikit dibandingkan yang diperoleh pada skoliosis idiopatik, serta tidak dapat mengharapkan untuk mendapatkan koreksi yang dramatis pada kurva kongenital yang besar dan kaku.

\section{Eksisi Hemivertebra}

Eksisi hemivertebra merupakan prosedur yang ideal untuk kurva panjang dengan deformitas yang signifikan atau ketidakseimbangan batang tubuh. Indikasi yang ideal adalah hemivertebra pada regio peralihan lumbosakral, karena kelainan tersebut sering menyebabkan ketidakseimbangan ataupun kurva kompensasi yang sangat serius.

Dengan teknik ini, dimungkinkan untuk penggabungan dengan hemiepiphysiodesis cembung dan/atau hemiarthrodesis, dengan menggunakan batang tak terfusi (nonfusion rod) atau instrumentasi definitif untuk kurva yang lebih panjang. Eksisi hemivertebra mungkin dilakukan dengan menggunakan kobinasi prosedur anterior dan posterior. Eksisi hemivertebra dengan prosedur posterior saja pada anak yang sedang bertumbuh baru-baru ini dilaporkan dengan hasil yang sukses. Ruf dan Harms melaporkan hasil pengamatan mereka pada eksisi hemivertebra menggunakan approach posterior saja dan instrumentasi transpedikular segmental. Mereka melaporkan hasil yang sangat baik pada pasien yang lebih muda dari 6 tahun, dengan pengukuran sudut $C o b b$ rata-rata $45^{\circ}$. Pada pemeriksaan lanjut setelah 3,5 tahun, pengukuran Cobb bertahan pada $14^{\circ}$, dengan tidak didapatkan pasien yang memiliki komplikasi neurologis.$^{10,14,26}$

\section{Osteotomi Rekonstruksi}

Kemiringan panggul, dekompensasi berat batang tubuh, deformitas progresif, dan berkembangnya defisit neurologis merupakan indikasi untuk osteotomi 
rekonstruksi. Hal tersebut dipertimbang-kan untuk kurva kaku dengan gangguan kosmetik kurang dapat diterima dan tidak berhasil diterapi dengan prosedur yang dijelaskan sebelumnya. Osteotomi dapat menjadi bagian dari teknik gabungan yang melibatkan reseksi dari hemivertebra dan instrumentasi dan fusi dari kurva yang lebih luas. Kurva yang kurang baik dari segi kosmetik namun seimbang paling baik diterapi dengan stabilisasi saja. ${ }^{10}$

\section{Thoracoplasty Perluasan dan VEPTR}

Pertumbuhan paru, cabang pernafasan, dan multiplikasi sel alveoli terutama pada usia 8 tahun pertama kehidupan. Dengan demikian, fusi dini mungkin memiliki dampak yang lebih besar pada pengembangan rongga dada dibandingkan pada tinggi tulang belakang. Dampak yang mungkin terjadi pada fusi tulang belakang dini pada perkembangan rongga dada dapat memperparah kekurangan volume rongga dada yang telah ada sebelumnya sehubungan dengan skoliosis kongenital dan tulang rusuk yang menyatu. ${ }^{27}$

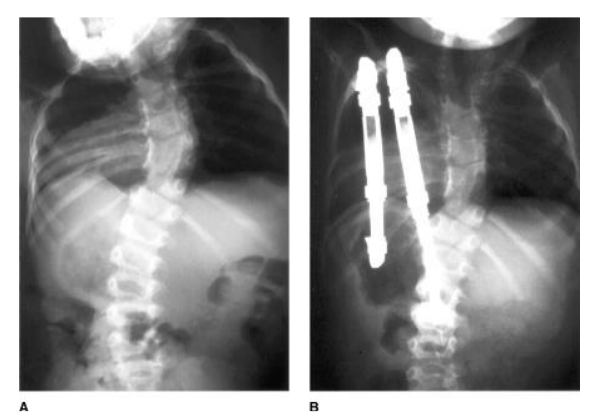

Gambar 13. (A) Radiografi anteroposterior pre-operasi pada pasien anak laki-laki usia 3 tahun dengan kelainan tulang belakang campuran dan penurunan volume rongga dada. (B) Radiografi pascaoperasi. ${ }^{17}$

Sebuah studi oleh Campbell dan Hell-Vocke menunjukkan penambahan panjang pada bar yang tidak tersegmentasi unilateral serta penambahan panjang yang seimbang antara sisi cekung dan cembung tulang belakang dada pada anak dengan skoliosis kongenital, tulang rusuk yang menyatu pada unilateral, dan bar tak tersegmentasi yang diterapi dengan VEPTR. Konsep bedah thoracoplasty ekspansi dan stabilisasi dengan implan VEPTR didasarkan pada perluasan rongga dada dengan pemisahan tulang rusuk pada sisi cekung kurva menyebabkan koreksi secara tidak langsung dari kurva, seperti pada gambar 13. Fusi tulang belakang mungkin diperlukan setelah maturitas tulang tercapai dan pertumbuhan tulang belakang toraks tidak lagi menjadi masalah. ${ }^{10,27}$

\section{RINGKASAN}

Tata laksana SK tetap menjadi aspek yang menantang dalam bidang orthopaedi anak. Dengan dikenalinya jenis malformasi tulang belakang, skoliosis kongenital dapat diklasifikasikan berdasarkan risiko perkembangan kurva sehingga tindak lanjut dapat disesuaikan. Skoliosis kongenital yang diakibatkan kegagalan segmentasi satu sisi vertebra memiliki prognosis yang buruk untuk progresivitas kurvatura dan deformitas.

Terapi operatif digunakan jika tidak terpenuhinya kriteria untuk terapi nonoperatif atau mengalami kegagalan.

\section{REFERENSI}

1. Mo F, Cunningham ME. Pediatric scoliosis. Curr Rev Musculoskelet. 2011; 4(4):175-182

2. Smith JS, Kasliwal MK, Crawford A, Shaffrey CI. Outcomes, expectations, and complications overview for the surgical treatment of adult and pediatric spinal deformity. Spine Deformity Preview Issue. 2012; 4-14

3. Kashani FO, Hasankani, EG, Baradaran A, Baghban N. Clinical outcomes of surgery in young patients with spinal deformity. Razavi Int J Med. 2015; 2(4): E23878

4. Cheung JYP. Focus on management of early-onset scoliosis. The British Editorial Society of Bone and Joint Surgery. 2013

5. Louis ML, Gennari JM, Loundou AD, et al. Congenital scoliosis: a frontal plane evaluation of 251 operated patients 14 
years old or older at follow-up. Orthopaedic \& Traumatology: Surgery \& Research. 2010; 96: 741-747

6. Giampietro PF. Congenital and idiopathoc scoliosis: clinical and genetic aspects. Scientifica. 2012. Article ID 152365. http://dx.doi.org/10.6064/2012/152365

7. Fletcher ND, McClung A, Rathjen KE, Denning JR, Browne R, Johnston JE. Serial casting as a delay tactic in the treatment of moderate-to-severe earlyonset scoliosis. J. Peiatr Orthop. 2012; 00:000-000

8. Mik G, Drummond DS, Hosalkar HS, et al. Diminished spinal cord size associated with congenital scoliosis of the thoracic spine. J Bone Joint Surg Am. 2009; 91:1698-704

9. Pediatric Orthopaedic Society of North America. Congenital scoliosis. 2015

10. Batra S, Ahuja S. Congenital Scoliosis: Management and Future Directions. Acta Orthop. Belg. 2008; 74: 147-160

11. Debnath UK, Goel V, Harshavardhana N, JK Webb. Congenital scoliosis - quo vadis? Indian J Orthop. 2010 AprilJune; 137-147

12. Asghar J. Congenital scoliosis. 2012. http://www.orthopaedicsone.com/displ ay/Main/Congenital+Scoliosis

13. McMaster JM, Mc Master ME. Prognosis for congenital scoliosis due to a unilateral failure of vertebral segmentation. J Bone Joint Surg Am. 2013; 95:972-9

14. Shah SA, Song Kit. Chapter 18: Congenital Scoliosis. 2013.

15. Redding GJ. Pulmonary review, early onset scoliosis: a pulmonary perspective. Spine Deformity. 2014; 2: 425-429

16. Hui H, Luo ZJ, Yan M, Ye ZX, Tao HR, Wang HQ. Non-Fusion and Growing Instrumentation in The Correction of Congenital Spinal Deformity Associated with Split Spinal Cord Malformation: An Early Follow-Up Outcome. Eur Spine J. 2013; 22: 13171325

17. Hedequist D, Emans J. Congenital Scoliosis. J Am Acad Orthop Surg. 2004; 12: 266-275

18. Cheneau J, Chekryzhev D, Mesentsev A, Petrenko D. The treatment of the congenital scoliosis by cheneau's brace: summary of the first experience. Scoliosis. 2009, 4(Suppl 1):O60
19. Grivas TB. European braces for conservative scoliosis treatment. InTech. 2012. http://www.intechopen.com/books/hum an-musculoskeletalbiomechanics/european-braces-forconservativescoliosis-treatment

20. Winter RB, Lonstein JE. Ultra-longterm follow-up of pediatric spinal deformity problems: 23 patients with a mean follow-up of 51 years. $J$ Orthop Sci. 2009; 14: 132-137

21. Kaspiris A, Grivas TB, Weiss HR, Turnbull D. Surgical and conservative treatment of patients with congenital scoliosis: $\alpha$ search for long-term results. Scoliosis. 2011; 6:12

22. Alanay A, Dede O, Yazici M. Convex instrumented hemiepiphysiodesis with concave distraction: a preliminary report. Clin Orthop Relat Res. 2012; 470:1144-1150

23. Wang S, Zhang J, Qiu G, Li S, Yu B, Weng $X$. Posterior hemivertebra resection with bisegmental fusion for congenital scoliosis: more than 3 years outomes and analysis of unanticipated surgeries. Eur Spine J. 2013; 22: 387393

24. Zhang J, Shengru W, Qiu G, Yu B, Yipeng W, Luk KDK. The efficacy and complications of posterior hemivertebra resection. Eur Spine J. 2011; 20: 16921702

25. Wang L, Song Y, Pei F, et al. Comparison of one-stage anteroposterior and posterior-alone hemivertebrae resection combined with posterior correction for hemivertebrae deformity. Indian Journal of Orthopaedics. 2011; 45: 492-499

26. Akbarnia, BA. Management Themes in Early Onset Scoliosis. J Bone \& Joint Surg. 2007; 89-A: 42-54

27. Dede O, Motoyama EK, Yang CI, et al. Pulmonary and radiographic outcomes of VEPTR (vertical expandable prosthetic titanium rib) treatment in early-onset scoliosis. J Bone \& Joint Surg. 2014; 96-A: 1295-302 